\title{
TERAPI LOGO DAN SUPORTIF KELOMPOK MENURUNKAN ANSIETAS REMAJA BINAAN RUTAN DAN LAPAS
}

\author{
Efri Widianti ${ }^{1{ }^{* *}}$, Mustikasari ${ }^{2}$, Agung Waluyo ${ }^{2}$ \\ ${ }^{1}$ Fakultas Keperawatan Universitas Padjadjaran, \\ Jalan. Raya Jatinangor-Sumedang KM. 21 Jatinangor, Sumedang, 45363, Indonesia \\ ${ }^{2}$ Fakultas Ilmu Keperawatan Universitas Indonesia \\ Jalan Prof. Dr. Bahder Djohan, Kampus UI Depok,16424, Indonesia \\ *)E-mail: efri.widianti@unpad.ac.id
}

Diterima: Maret 2017, diterbitkan: Desember 2017

\begin{abstract}
Abstrak
Latar belakang: Remaja yang harus menjalani masa masa hukuman akibat tindak kriminal yang pernah dilakukannya sangat rentan mengalami ansietas. Ansietas sebagai salah satu masalah psikososial dapat diatasi dengan beberapa psikoterapi diantaranya terapi logo dan terapi suportif. Tujuan: Tujuan penelitian ini untuk mengetahui pengaruh terapi logo dan terapi suportif terhadap ansietas remaja di rumah tahanan dan lembaga pemasyarakatan wilayah Jawa Barat. Metode: Desain yang digunakan dalam penelitian ini adalah quasi experiment pre-post test with control group dengan 78 responden yang merupakan hasil screening berdasarkan kriteria inklusi, terdiri dari 39 responden untuk kelompok intervensi dan 39 responden untuk kelompok kontrol. Terapi ini diberikan dalam 8 sesi yang terdiri dari terapi logo 4 sesi dan terapi suportif 4 sesi. Penelitian ini dilakukan selama 5 minggu. Instrumen yang digunakan dalam penelitian ini adalah State Trait Anxiety Scale-Trait yang telah dilakukan uji validitas dengan nilai r=0,313-0,574 dan nilai reliabilitas=0,770 pada 30 orang remaja di lapas yang terdapat di Kabupaten Garut. Data yang didapatkan dianalisis menggunakan uji independent t test, chi-square dan marginal homogenity. Hasil Penelitian: Hasil penelitian menunjukkan adanya pengaruh terapi logo dan terapi suportif terhadap penurunan tingkat ansietas remaja yang ditunjukkan dengan $p$ Value $=0.000(\alpha=0.05)$. Kesimpulan: Terapi logo dan suportif kelompok dapat menurunkan ansietas pada remaja. Rekomendasi penelitian ini ditujukan kepada Kanwil Hukum dan HAM Provinsi Jawa Barat selaku pemegang kebijakan untuk memberikan perhatian terhadap permasalahan psikologis pada warga binaan dengan mengembangkan kegiatan kegiatan kelompok serta bekerja sama dengan pihak akademik dan layanan kesehatan jiwa dalam upaya untuk mencegah dan mengatasi masalah kesehatan jiwa pada warga binaan.
\end{abstract}

Kata kunci: ansietas remaja, terapi logo, terapi suportif

\section{GROUP LOGO AND SUPORTIVE THERAPIES REDUCE ANXIETY IN ADOLESCENTS AT STATE DETENSION HOUSE AND PRISON}

\section{Abstract}

Background: Adolescents who have to receive a sentence due to crimes they committed are very susceptible to anxiety. A psychosocial problem, anxiety can be overcome with several psychotherapies, including logo therapy and supportive therapy. Objective: This study aims to identify the effect of logo therapy and supportive therapy on anxiety in adolescents at state detention house and prison in West Java. Methods: This study used a quasi-experiment pre-posttest with control group design with 78 respondents who were screened based on the inclusion criteria, consisting of 39 respondents for the intervention group and 39 respondents for the control group. This therapy was given in 8 sessions, consisting of 4 sessions for logo therapy and 4 sessions for supportive therapy. This study was conducted for 5 weeks. It used State Trait Anxiety Scale-Trait of which validity and reliability had been tested with $r$ value $=0.313-0.574$ and reliability $=0.770$ in 30 adolescents at a prison in Garut Regency. The data obtained were analyzed using independent t test, chi-square test and 
marginal homogeneity. Results: The results showed the effect of logo therapy and supportive therapy on the reduction in the levels of anxiety in adolescents as shown by $p$ value $=0.000(\alpha=0.05)$. Conclusion: The group logo and supportive therapy can reduce anxiety in adolescents. This research recommends the Regional Office of Law and Human Rights of West Java Province as the policy maker give attention to psychological problems in prisoners by developing group activities and collaborating with academics and mental health services to prevent and overcome mental health problems in prisoners. Keywords: anxiety in adolescents, logo therapy, supportive therapy

\section{Latar Belakang}

Remaja adalah masa ketika seorang individu rentan terhadap terjadinya masalah psikososial, dimana individu tersebut mengalami suatu masa peralihan dari masa kanak-kanak ke dewasa (Steinberg, 2005). Hurlock (1999) dalam Goulet \& Baltes (2013) memberi batasan usia kronologis remaja yaitu antara 13 hingga 18 tahun. Remaja sering dihubungkan dengan penyimpangan dan ketidakwajaran, karena adanya perubahan yang terjadi pada masa remaja meliputi perubahan biologis, kognitif dan sosial emosional (Santrock, 2015).

Perubahan biologis ditandai dengan perubahan seluruh ukuran badan remaja. Pada remaja perempuan pinggang menjadi kecil, pinggul membesar, payudara membesar, terjadi menstruasi sedangkan pada anak lali-laki bahu melebar, ukuran muka juga berubah, hidung dan rahang menjadi lebih menonjol dan kening menjadi lebih tinggi dan mengalami mimpi basah. Perubahan kognitif pada remaja ditandai dengan remaja mulai berfikir secara independen dan mengambil keputusan sendiri, merasa perlu mengumpulkan pengalaman baru kemudian mengujinya meskipun berisiko, intelektual lebih berkembang, dan mampu berfikir abstrak. Perubahan sosial emosional ditandai dengan mulai membutuhkan lebih banyak teman dan setiakawan, mulai menyukai lawan jenis, perilaku memberontakan melawan, menyatakan kebebasan dan merasa sebagai seorang individu, tidak hanya sebagai seorang anggota keluarga (Departemen Kesehatan Republik Indonesia, 2016).
Perubahan-perubahan yang terjadi pada masa remaja tersebut membuat remaja menjadi pribadi yang penuh gejolak emosi serta dipenuhi ketidakseimbangan sehingga mudah terpengaruh oleh lingkungan. Keingintahuan yang besar pada remaja, pengaruh negatif media dan lingkungan bermain, kondisi keluarga yang kurang kondusif (kesibukan orangtua, pola asuh yang kurang tepat, dan kondisi keluarga yang kurang harmonis) menjadi faktor yang berpengaruh terhadap penyimpangan pada masa remaja (Masngudin, 2004).

Salah satu bentuk penyimpangan pada masa remaja adalah kasus kriminal yang dilakukan oleh remaja antara lain melanggar ketertiban, kejahatan susila, penganiayaan, pencurian, perampokan, kejahatan narkotika, penggunaan senjata tajam, dan kekerasan terhadap anak. Kasus-kasus tersebut membawa remaja berurusan dengan lembaga hukum dan beberapa remaja yang divonis bersalah kemudian menjalani masa masa berada di rumah tahanan (rutan) sebagai narapidana.

Setiap tahunnya terdapat lebih dari 4.000 perkara pelanggaran hukum yang dilakukan anak-anak di bawah usia 16 tahun. Dari seluruh anak yang ditangkap sekitar separuhnya diajukan ke pengadilan dan 83 persen dari mereka kemudian dipenjarakan. Hingga tahun 2002, terdapat 3,722 "anak didik" di Lembaga Pemasyarakatan (LAPAS) Anak (Departemen Kehakiman dan HAM, Agustus 2002 dalam Irawan, 2011). Kasus terbanyak anak-anak yang berhadapan 
dengan hukum adalah pencurian (60 persen) dan perkelahian (13 persen). Anak yang berkonflik dengan hukum meliputi juga Anak Nakal yaitu anak yang melakukan tindak pidana atau anak yang melakukan perbuatan yang dinyatakan terlarang bagi anak. Hingga tahun 2002, jumlah Anak Nakal yang dikategorikan sebagai penyandang masalah kesejahteraan sosial mencapai sekitar 193.155 orang (Departemen Sosial Republik Indonesia, 2002).

Remaja yang menjalani pidana penjara dituntut untuk mampu beradaptasi dan bersosialisasi dengan peraturan penjara yang sangat menekan, rutinitas kehidupan penjara yang sangat membosankan, dan kehidupan sosial bersama narapidana lain yang sering terjadi keributan, pemerasan, dan tindakan kekerasan yang dirasakan sebagai suatu penderitaan lain disamping hukuman pidana sendiri (Van der Laan \& Eichelsheim, 2013). Hal tersebut menyebabkan remaja merasa tidak berharga di bandingkan dengan anak seusianya, mendapat celaan dari orang lain, merasa tidak punya harapan, merasa gagal sehingga pada akhirnya dapat menimbulkan depresi (Manik, 2007).

Beberapa masalah yang sering menjadi konflik pribadi para narapidana anak yang merupakan stressor kecemasan antara lain: 1) takut tidak diterima oleh lingkungannya; 2) rasa malu bergaul untuk kembali pada lingkungannya; 3) gangguan harga diri; dan 4) masyarakat condong untuk menjauhi mereka (Van der Laan \& Eichelsheim, 2013). Berdasarkan penelitian yang dilakukan oleh Zhou et al. (2014) disebutkan bahwa terdapat hubungan yang negatif antara konsep diri dengan tingkat kecemasan narapidana remaja, dimana semakin rendah konsep diri remaja maka semakin tinggi tingkat ansietas yang dirasakan. Hal ini diperkuat oleh penelitian yang dilakukan oleh Collins et al. (2010) yang menyebutkan bahwa $20,3 \%$ remaja yang menjalani masa hukuman mengalami ansietas.

Upaya untuk menangani ansietas antara lain dengan penggunaan psikofarmaka dan psikoterapi. Townsend (2009) menyebutkan bahwa penggunaan obat-obatan anti ansietas dapat menyebabkan depresi susunan syaraf pusat secara menyeluruh sehingga apabila digunakan secara terus menerus dapat berpotensi menyebabkan ketergantungan fisik atau psikologis. Penggunaan obat obatan anti ansietas tidak di anjurkan diberikan dalam jangka panjang. Selain pendekatan psikofarmaka, penanganan ansietas dapat dilakukan dengan pendekatan psikoterapi.

Salah satu psikoterapi yang dapat diterapkan sebagai solusi masalah ansietas adalah terapi logo. Terapi logo dapat dilakukan pada kasus psikososial seperti cemas, insomnia, migrain, rasa kehilangan karena penyakit atau kematian, disorientasi, anak-anak yang resisten, anoreksia nervosa, pobia neurosis, dan pada kasus psikotik seperti pikiran dan perilaku obsesif kompulsif, multiple personality disorder, conversion disorder (Hage, 2006). Menurut Canadian Psychiatric Association (2006) penggunaan terapi logo pada klien yang mengalami ansietas dilakukan untuk membentuk nilainilai. Hal ini sejalan dengan pernyataan yang disampaikan oleh Bastaman (2007) bahwa inti dari terapi logo adalah hasrat untuk hidup lebih bermakna (the will to meaning), menemukan makna hidup (the meaning of life) dan mengembangkan hidup bermakna (the meaningfull life) sehingga dengan motto "meaning in suffering" dan bersifat "future oriented" diharapkan optimisme dalam menghadapi masa depan mampu bangkit.

Terapi logo dilaksanakan dalam bentuk konseling dan beorientasi pada pencarian makna hidup individu. Tujuan terapi logo meningkatkan makna pengalaman hidup individu yang diarahkan kepada 
pengambilan keputusan yang bertanggung jawab (Bastaman, 2007). Pada terapi logo, individu diajarkan tetap bersikap positif, dan mengambil makna dalam kondisi yang paling sulit, untuk dapat hidup lebih baik. Narapidana remaja yang mengalami perubahan sosial dan kehilangan kasih sayang dari orang tua karena pemisahan akibat hukuman pidana yang harus dijalani menyebabkan terjadinya krisis makna yang akhirnya menurunkan motivasi untuk hidup, sehingga dalam kondisi semacam ini penggunaan terapi logo menjadi penting (Blair, 2004).

Sutejo (2009) mengungkapkan dalam penelitiannya tentang pengaruh terapi logo dengan menggunakan teknik paradoxical intension terhadap kecemasan pada penduduk pasca gempa di Klaten bahwa terapi logo dengan teknik paradoxical intension mempunyai pengaruh yang bermakna dalam mengatasi ansietas penduduk pasca gempa akan tetapi apabila dilihat pada masing-masing subvariabel (fisiologis, afektif, kognitif, dan perilaku) diketahui bahwa pada subvariabel afektif tidak menunjukkan pengaruh yang signifikan, hanya terjadi peningkatan nilai saja.

Hal ini kemudian dijadikan dasar oleh Wijayanti (2010) yang melakukan penelitian tentang pengaruh terapi logo terhadap ansietas pada narapidana perempuaan di Lapas Semarang. Pada penelitian ini Wijayanti menambahkan satu teknik lagi dalam terapi logo untuk mengatasi ansietas yaitu teknik derefleksion dan hasil dari penelitian Wijayanti menunjukkan hal yang sama dengan penelitian Sutejo dimana secara komposit nilai penggunaan terapi logo dengan teknik paradoxical intension dan derefleksi mempunyai pengaruh yang signifikan terhadap ansietas pada narapidana perempuan tapi untuk subvariabel afektif hanya terjadi perubahan nilai, dan tidak menunjukkan pengaruh yang signifikan.
Oleh karena itulah berdasarkan penjelasan di atas maka peneliti akan menerapkan terapi logo dengan teknik paradoxical intention dan dereflection dengan penambahan psikoterapi lain yang diperlukan untuk mengatasi masalah ansietas.

Psikoterapi lain yang dipergunakan untuk mengatasi ansietas adalah terapi suportif. Terapi suportif adalah suatu bagian dari psikoterapi yang digunakan pada komunitas berbasis psikatrik. Berbeda dari model yang lain, terapi suportif tidak tergantung pada konsep atau teori yang spesifik. Terapi suportif umumnya menggunakan psikodinamik untuk memahami bagaimana seseorang dapat berubah (Viederman, 2008). Terapi suportif sangat efektif dalam mengatasi ansietas (Viederman, 2008; Lipsitz et al., 2008 ). Pada remaja di rumah tahanan dengan ansietas, terapi suportif membantu menjelaskan kepada remaja tentang respon koping biopsikososial, mengenal sumber koping dan menggunakan sumber-sumber koping yang telah diidentifikasi untuk mengatasi ansietas yang dialami sehingga ansietas dapat dicegah atau dikurangi (Lipsitz, 2008).

Berdasarkan penelitian yang dilakukan Oliva, Jiménez, \& Parra (2009) diketahui bahwa remaja sangat membutuhkan dukungan dari orang yang ada di sekitarnya terutama keluarga dalam menghadapi stressor yang mengikuti tugas perkembangan yang mereka hadapi sehingga pengenalan terhadap sumber pendukung yang dimiliki oleh remaja sangat diperlukan. Pengenalan terhadap sumber koping yang dimilki oleh remaja dan bagaimana penggunaannya didapatkan dari terapi suportif (Viederman, 2008).

Sadock \& Sadock (2011) menjelaskan bahwa kombinasi 2 psikoterapi dalam mengatasi masalah mental emosional lebih efektif dibandingkan hanya penggunaan salah satu terapi. Dua terapi yang 
digabungkan akan saling melengkapi satu sama lain dan memperbesar efektivitas yang lain. Pada penelitian ini penggabungan dua psikoterapi yang telah dijelaskan di atas diharapkan dapat membantu meningkatkan kemampuan narapidana remaja mengatasi ansietas dimana narapidana akan diajak untuk menemukan makna hidup dengan mengambil hikmah atas setiap kejadian yang telah dialami untuk kemudian dilanjutkan dengan memfasilitasi narapidana remaja menemukan sumber-sumber yang dapat di gunakan untuk mengatasi ansietas yang sering mereka rasakan. Dibandingkan dengan penggunaan salah satu terapi diharapkan pula penggabungan kedua terapi ini secara bertahap dapat memberikan hasil yang lebih optimal dalam mengatasi masalah ansietas pada remaja di rumah tahanan dimana remaja tidak hanya mengalami penurunan ansietas pada saat dilakukan terapi tapi remaja juga mampu mempraktekkan terapi yang telah dilatihkan jika di kemudian hari ansietas yang dialami muncul kembali.

Berdasarkan studi pendahuluan yang dilakukan di Rumah Tahanan Negara Kelas 1 Bandung diketahui bahwa jumlah total narapidana dan tahanan penghuni rutan per 1 Februari 2011 adalah 756 orang. Dari 756 orang tersebut diantaranya terdapat remaja 40 orang dengan status tahanan 22 orang dan 18 orang dengan status narapidana yang usianya berkisar antara 13 sampai dengan 18 tahun dengan keseluruhan berjenis kelamin laki-laki. Kasus yang menyebabkan mereka harus dipenjara bervariasi, yaitu kejahatan terhadap ketertiban, kejahatan susila, penganiayaan, pencurian, perampokan, penyalahgunaan Narkotika, Psikotropika dan Zat Adiktif (NAPZA), membawa senjata tajam dan kekerasan terhadap anak. Masa hukuman pun bervariasi tergantung pada kasus. Sebagian besar dari narapidana anak dijatuhi hukuman kurang dari 1 tahun. Tidak ada narapidana anak yang dihukum seumur hidup dan sebagian hakim lebih memilih memberikan putusan hukuman penjara dari pada hukuman tahanan atau denda.

Suasana penjara yang tak ramah dan adanya banyak masalah seperti kelebihan penghuni, terbatasnya sarana dan prasarana, tidak ada fasilitas khusus untuk anak, dan gaya komunikasi pegawai lapas/rutan dapat menyebabkan anak merasa mempersalahkan diri dan inferioritas, tak layak kembali ke lingkungan, serta ketakutan menghadapi stigma masyarakat (Supeno, 2009).

Itu berarti pula bahwa akan semakin besar kemungkinan narapidana untuk gagal dalam memaknai keberadaan mereka sebagai narapidana sehingga banyak diantara mereka akhirnya menjadi residivis. Mereka akan kehilangan kemampuan untuk berpikir secara jernih bahwa sesungguhnya mereka masih memiliki tanggung jawab sosial sebagai manusia. Ketidakmampuan mereka untuk berpikir demikian pada gilirannya akan membentuk mereka menjadi pribadi yang neurosis yang akan berujung pada hadirnya kecemasan yang berlebihan, hingga dapat melumpuhkan kemampuan mereka untuk bertindak sewajarnya, dan membuat kepribadiannya menjadi panik (Maya, 2008).

Berdasarkan studi dokumentasi pada bulan Januari 2011 di rumah tahanan kelas I Bandung tentang masalah psikososial yang sering muncul dan dialami oleh anak didik laki laki diketahui dari 33 anak didik 16 orang diantaranya mengalami masalah ansietas dan dari 16 orang tersebut $80 \%$ mengalami ansietas sedang, 5\% mengalami ansietas berat dan sisanya mengalami ansietas ringan (Program Profesi Ners Universitas Padjajaran, 2011).

Banyaknya jumlah remaja yang mengalami ansietas di rumah tahanan belum menjadi perhatian khusus bagi pihak rutan. Hal ini disebabkan oleh keterbatasan jumlah tenaga 
ahli yang berfokus pada masalah psikososial yang terjadi pada narapidana khususnya remaja. Kondisi ini ditambah dengan belum adanya kebijakan khusus di wilayah Jawa Barat terkait dengan penanganan remaja yang menjadi anak didik di rumah tahanan dan lembaga pemasyarakatan sehingga pembinaan remaja disamakan dengan orang dewasa.

Berdasarkan data dari studi pendahuluan di atas dan belum adanya penelitian tentang terapi logo dan terapi suportif pada remaja dengan ansietas di rumah tahanan atau lembaga pemasyarakatan maka peneliti tertarik untuk melakukan penelitian tentang pengaruh terapi logo dan terapi ansietas di rumah tahanan dan lembaga pemasyarakatan wilayah Jawa Barat.

\section{METODE}

Penelitian ini adalah penelitian quasi experimental dengan metode kuantitatif menggunakan desain "Quasi experimental pre-post test with control group" dengan intervensi terapi logo dan terapi suportif kelompok pada remaja pada tanggal 2 Mei sampai dengan 8 Juni 2011 di suatu rutan di wilayah Kota Bandung dan Kabupaten Bandung. Teknik pengambilan sampel dengan cara consecutive sampling. Berdasarkan hasil screening dan kriteria inklusi didapatkan kelompok intervensi berjumlah 39 responden dan kelompok kontrol berjumlah 39 responden.

Tingkat ansietas diukur dengan menggunakan kuesioner State Trate Anxiety for Children-Trait (STAIC-T) yang terdiri dari 20 pernyataan yang seluruhnya bersifat unfavorable, dengan skor jawaban 4=selalu, 3=sering, 2=kadang kadang, dan $1=$ tidak pernah. Seorang remaja dikatakan mengalami ansietas ringan jika skornya 20-35, ansietas sedang jika skornya 3650 , ansietas berat jika skornya 51-65, dan panik jika skornya 66-80. Kuesioner ini telah dilakukan uji validitas dengan nilai $r$ hitung 0.313-0.574 dan reliabilitas dengan nilai 0.770 pada 30 orang di rumah tahanan di wilayah Kabupaten Garut.

Penelitian dilakukan untuk menganalisis perubahan tingkat ansietas remaja sebelum dan sesudah terapi logo dan terapi suportif kelompok pada remaja di rutan dan lapas wilayah Jawa Barat dan membandingkan antara kelompok yang mendapatkan terapi logo dan terapi suportif kelompok dengan kelompok yang tidak mendapatkan terapi logo dan terapi suportif kelompok.

Pada penelitian ini kelompok perlakukan terdiri dari 4 kelompok dan kelompok kontrol terdiri dari 4 kelompok. Pada kelompok perlakuan, terapi logo dilakukan dalam 4 sesi pada masing masing kelompok dan terapi supportif dilakukan dalam 4 sesi pada masing masing kelompok. Setiap sesi berlangsung selama 45 menit/hari. Terapi logo dan terapi suportif ini dilakukan oleh peneliti. Proses pelaksanaan penelitian ini membutuhkan waktu 5 minggu. Sebelum pelaksanaan pengambilan data peneliti memberikan penjelasan terlebih dahulu kepada responden dan setelah responden memahami dan menyetujui untuk ikut dalam kegiatan penelitian ini responden menandatangani lembar persetujuan/ kesediaan menjadi responden. Analisis statistik yang dipergunakan yaitu univariat dan bivariat dengan analisis t-test, chi-square, serta marginal homogenity dengan tampilan dalam bentuk tabel dan distribusi frekuensi. 
1. Hasil

Tabel 1 Analisis Kesetaraan Karakteristik Usia dan Penghasilan pada Kelompok Kontrol dan Kelompok Intervensi di Rutan dan Lapas Wilayah Jawa Barat

\begin{tabular}{|c|c|c|c|c|c|c|c|}
\hline \multicolumn{8}{|c|}{ Bulan Mei-Juni $2011\left(n_{1}=39, n_{2}=39\right)$} \\
\hline Variabel & Kelompok & $\mathbf{n}$ & Mean & SD & SE & $T$ & p value \\
\hline Usia & Intervensi & 39 & 16,74 & 0,785 & 0,126 & 1,090 & 0,305 \\
\hline (dalam tahun) & Kontrol & 39 & 16,97 & 1,063 & 0,170 & & \\
\hline Penghasilan & Intervensi & 39 & 725,64 & 819,81 & 131,27 & 1,404 & 0,217 \\
\hline $\begin{array}{l}\text { (dalam } \\
\text { ratusan ribu) }\end{array}$ & Kontrol & 39 & 1016,67 & 1001,47 & 160,36 & & \\
\hline
\end{tabular}

Tabel 2 analisis kesetaraan tingkat ansietas, tingkat pendidikan dan pola asuh orangtua remaja di Rumah Tahanan dan Lembaga Pemasyarakatan Sebelum Pelaksanaan Terapi Logo dan Terapi Suportif di Wilayah Jawa Barat

Mei-Juni $2011\left(n_{1}=39, n_{2}=39\right)$

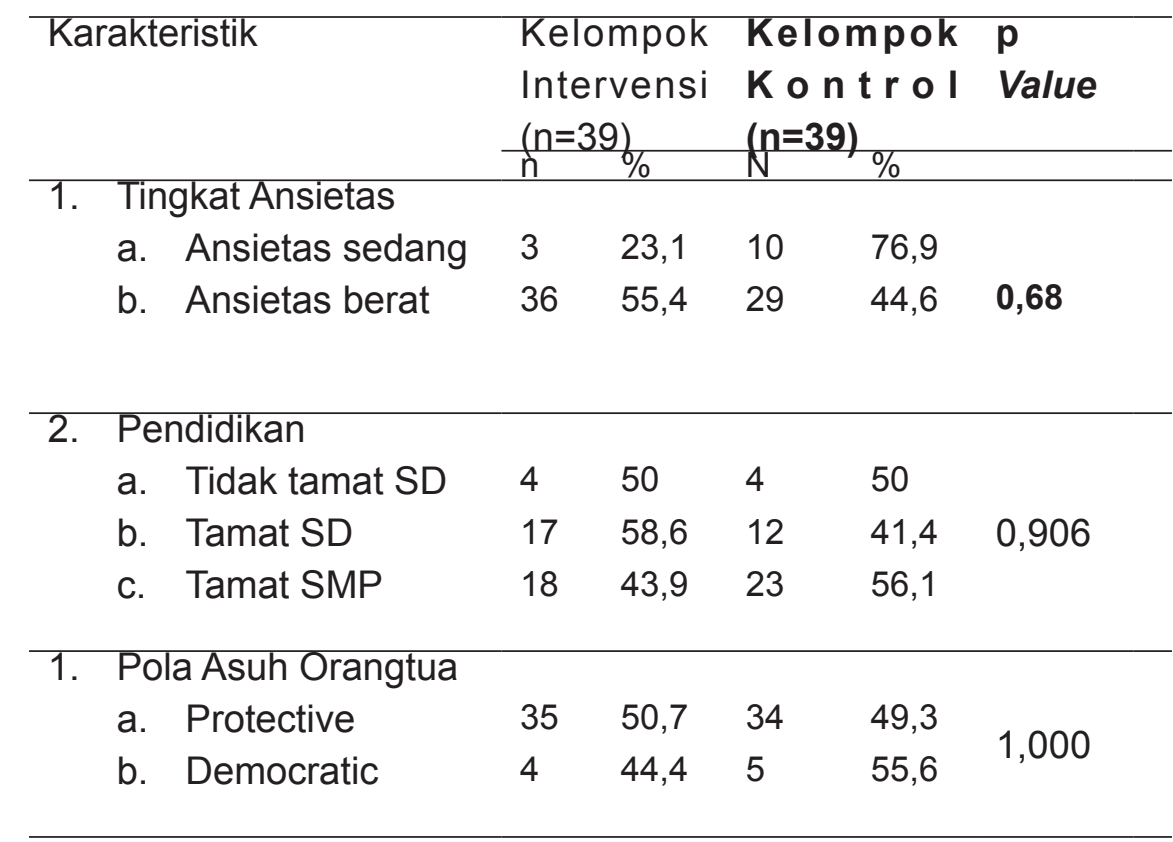

Karakteristik remaja dalam penelitian ini menunjukkan bahwa remaja pada kelompok intervensi dan kontrol rata-rata berusia 16,74 tahun dan remaja pada kelompok kontrol ratarata berusia 16,97. Rata-rata penghasilan orangtua remaja pada kelompok intervensi sebesar Rp. 725.640 dan penghasilan orangtua remaja pada kelompok kontrol sebesar Rp. 1.016.670 (Tabel 1). Sebagian besar remaja pada kelompok intervensi dan kelompok kontrol berpendidikan terakhir tamat SMP, dan orangtua remaja menerapkan pola asuh protective dalam perspektif remaja (Tabel 2). Karakteristik pada kelompok control dan kelompok intervensi yang ditunjukkan pada tabel diatas setara. Hal ini dapat terlihat dari nilai $p$ value antara kedua kelompok menunjukkan $>0,05$. 
Tabel 3. Analisis Tingkat Ansietas Remaja Sebelum dan Sesudah Intervensi pada Kelompok Kontrol di Rutan dan Lapas Wilayah Jawa Barat Bulan Mei-Juni 2011 (n=39)

\begin{tabular}{|c|c|c|c|c|c|c|c|}
\hline & \multicolumn{2}{|c|}{ Ansietas sedang } & \multicolumn{2}{|c|}{ Ansietas berat } & \multicolumn{2}{|c|}{ TOTAL } & \multirow{2}{*}{$p$ value } \\
\hline & $\mathrm{n}$ & $\%$ & $\mathrm{n}$ & $\%$ & $\mathrm{n}$ & $\%$ & \\
\hline Pre test & 10 & 25,6 & 29 & 74,4 & 39 & \multirow{2}{*}{$\begin{array}{l}100 \\
100\end{array}$} & \multirow{2}{*}{1,000} \\
\hline Post test & 10 & 25,6 & 29 & 74,4 & 39 & & \\
\hline
\end{tabular}

Hasil analisis statistik untuk kelompok kontrol (Tabel 3) menunjukkan bahwa tidak terjadi perubahan tingkat ansietas remaja sebelum dan setelah diberikan intervensi berupa pendidikan kesehatan dengan tema cara mengatasi ansietas. Hal ini ditunjukkan berdasarkan uji statistik, dengan nilai $p$ value sebesar 1,000 berada di atas nilai

Tabel 4. Analisis Tingkat Ansietas Remaja

Sebelum dan Sesudah Terapi Generalis, Terapi Logo, dan Terapi Logo + Terapi Suportif pada Kelompok Intervensi di Rutan dan Lapas Wilayah Jawa Barat Bulan Mei-Juni 2011 (n=39)

\begin{tabular}{|c|c|c|c|c|c|c|c|c|}
\hline & & \multicolumn{2}{|c|}{ Ansietas sedang } & \multicolumn{2}{|c|}{ Ansietas berat } & \multicolumn{2}{|c|}{ TOTAL } & \multirow[b]{2}{*}{$p$ value } \\
\hline & & $\mathrm{n}$ & $\%$ & $\mathrm{n}$ & $\%$ & $n$ & $\%$ & \\
\hline \multirow[t]{2}{*}{ Terapi generalis } & Pre test & 3 & 7,7 & 36 & 92,3 & 39 & 100 & \multirow{2}{*}{0,157} \\
\hline & Post test & 4 & 10,3 & 35 & 89,7 & 39 & 100 & \\
\hline \multirow[t]{2}{*}{ Terapi logo } & Pre test & 3 & 7,7 & 36 & 92,3 & 39 & 100 & \multirow[b]{2}{*}{0,001} \\
\hline & Post test & 13 & 33,3 & 26 & 66,7 & 39 & 100 & \\
\hline \multirow{2}{*}{$\begin{array}{l}\text { Terapi logo } \\
\text { +suportif }\end{array}$} & Pre test & 3 & 7,7 & 36 & 92,3 & 39 & 100 & \multirow[b]{2}{*}{$<0,001$} \\
\hline & Post test & 33 & 84,6 & 6 & 15,4 & 39 & 100 & \\
\hline
\end{tabular}

Berdasarkan hasil uji statistik pada Tabel 4 di atas diketahui pada kelompok intervensi tidak terdapat perbedaan yang signifikan pada tingkat ansietas sebelum dan setelah terapi generalis ditandai dengan $p$ value $(0,157)>0,05$. setelah dilakukan terapi generalis dan diukur tingkat ansietas remaja dilakukan terapi logo. Setelah terapi logo dilakukan pengukuran ansietas kembali dan di analisa dengan menggunakan uji marginal homogenity dan hasil uji tersebut didapatkan terdapat perbedaan tingkat ansietas sebelum dilakukan terapi dan sesudah dilakukan alpha $(p>0,05)$, sehingga dapat disimpulkan bahwa pemberian terapi generalis berupa pendidikan kesehatan tentang ansietas belum mampu mengubah tingkat ansietas remaja yang mengalami masa-masa hukuman di rutan dan lapas, sehingga dibutuhkan terapi spesialis sebagai terapi lanjutan. 
Tabel 5. Analisis Tingkat Ansietas Remaja

Setelah Dilakukan Terapi Logo dan Terapi Suportif pada Kelompok Intervensi dan kelompok Kontrol di Rutan dan Lapas Wilayah Jawa Barat Bulan Mei-Juni $2011\left(n_{1}=39, n_{2}=39\right)$

\begin{tabular}{|c|c|c|c|c|c|c|c|}
\hline \multirow[t]{2}{*}{ Karakteristik } & \multicolumn{2}{|c|}{ Kelompok Intervensi ( $n=39$ ) } & \multicolumn{2}{|c|}{ Kelompok Kontrol ( $n=39)$} & \multicolumn{2}{|c|}{$\begin{array}{l}\text { Jumlah } \\
\text { (n=78) }\end{array}$} & \multirow{2}{*}{$\begin{array}{c}\mathrm{p} \\
\text { Value }\end{array}$} \\
\hline & \multirow[t]{2}{*}{$\mathrm{n}$} & \multirow[t]{2}{*}{$\%$} & \multirow[t]{2}{*}{$\mathrm{N}$} & \multirow[t]{2}{*}{$\%$} & $\mathrm{n}$ & $\%$ & \\
\hline $\begin{array}{l}\text { Tingkat } \\
\text { ansietas }\end{array}$ & & & & & & & $<0,001$ \\
\hline $\begin{array}{l}\text { Ansietas } \\
\text { sedang }\end{array}$ & 33 & 84,6 & 10 & 25,6 & 43 & 55,1 & \\
\hline $\begin{array}{l}\text { Ansietas } \\
\text { berat }\end{array}$ & 6 & 15,4 & 29 & 74,4 & 35 & 44,9 & \\
\hline TOTAL & 39 & 100 & 39 & 100 & 78 & 100 & \\
\hline
\end{tabular}

Tabel 5 menunjukkan bahwa pada kelompok intervensi diketahui proporsi remaja dengan tingkat ansietas sedang sebesar $84.6 \%$, dan ansietas berat sebesar $15.4 \%$. Sedangkan pada kelompok kontrol diketahui proporsi remaja dengan tingkat ansietas sedang $25.6 \%$, dan ansietas berat $74.4 \%$. Pada kelompok kontrol dan kelompok intervensi tidak ditemukan ansietas ringan, sebagian besar responden pada kelompok kontrol setelah menjalani terapi generalis ansietas masih mengalami ansietas berat. Hasil uji statistik menunjukkan bahwa terdapat perbedaan yang signifikan tingkat ansietas remaja antara kelompok intervensi dan kelompok kontrol dengan nilai $p=0,000$ $(p<0,05)$. Sehingga dapat disimpulkan bahwa pemberian terapi logo dan terapi suportif mampu menimbulkan perbedaan tingkat ansietas remaja antara kelompok intervensi yang memperoleh terapi logo dan terapi suportif dengan kelompok kontrol yang hanya memperoleh terapi generalis.

\section{DISKUSI}

Pada kelompok kontrol diketahui bahwa tidak terdapat perbedaan ansietas remaja sebelum dan setelah diberikan pendidikan keehatan tentang ansietas. Hal ini sejalan dengan penelitian yang dilakukan oleh Fergusson, Boden, \& Horwood (2007) yang menjelaskan bahwa pendidikan kesehatan tentang ansietas dan cara mengatasinya tidak berpengaruh terhadap penurunan tingkat ansietas remaja. Anak-anak dapat belajar tentang sikap dan perilaku untuk memelihara dan meningkatkan kesehatan mereka melalui pendidikan kesehatan, tetapi mereka juga membutuhkan bimbingan dan model peran sehingga mereka bisa menggunakannya ketika sewaktu-waktu mereka merasa cemas dan perlu untuk mengatasinya. Model dan peran yang dibutuhkan anak-anak ini sangat sulit ditemukan karena mayoritas orang dewasa tidak bertindak sebagai model peran yang tepat bagi anak-anak (Omizo \& Omizo, 1992 dalam Santrock 2015).

Namun demikian, hasil penelitian ini bertentangan dengan penelitian yang dilakukan oleh Bektas \& Ozturk (2008) yang menyebutkan bahwa pendidikan kesehatan mempunyai pengaruh yang signifikan terhadap tingkat ansietas. Penelitian lain menyebutkan bahwa pendidikan kesehatan 
untuk mengatasi ansietas pada remaja diarahkan pada berbagai tema seperti managemen stress, pengembangan diri dan relaksaasi terpimpin. Selain Bektas \& Ozturk (2008), beberapa penelitian lain telah membuktikan adanya pengaruh pemberian terapi generalis terhadap penurunan ansietas. Sebuah penelitian yang dilakukan oleh Fiandini (2010) menemukan bahwa relaksasi nafas dalam mampu secara efektif menurunkan tingkat ansietas pasien pre operasi di ruang bedah. Hasil tersebut sesuai dengan pernyataan Prawitasari (1998, dalam Asrori, 2016) yang mengungkapkan bahwa teknik relaksasi juga dapat digunakan sebagai keterampilan koping yang aktif dalam kondisi ansietas. Penelitian tentang teknik reduksi ansietas lainnya, diungkapkan pula oleh Mu`afiro (2004). Hasil dari penelitian tersebut membuktikan bahwa teknik hipnotik lima jari cukup efektif untuk menurunkan tingkat ansietas pasien kanker leher rahim di ruang kandungan RSU Dr Soetomo Surabaya.

Pada penelitian ini, tidak adanya pengaruh yang signifikan pada pendidikan kesehatan yang dilakukan disebabkan oleh tingkat ansietas remaja pada variabel perancu kelompok kontrol sebagian besar adalah ansietas berat dimana pada tingkat ansietas berat, remaja mengalami kesulitan dalam berkonsentrasi dan tidak bisa fokus pada satu hal tertentu (Videbeck, 2008). Selain hal tersebut, faktor lain yang bisa menyebabkan tidak adanya pengaruh yang signifikan pada pendidikan kesehatan adalah pendidikan kesehatan dilakukan dalam satu ruang dengan jumlah responden yang cukup besar (pada lapas Sukabumi=28 responden) sehingga tidak semua responden bisa diperhatikan oleh terapis.

Pendidikan kesehatan merupakan suatu metode yang cukup baik untuk meningkatkan pengetahuan remaja terhadap masalah yang di alaminya. Pada pendidikan kesehatan yang dilakukan terhadap remaja akan lebih punya manfaat terhadap perubahan perilaku pada remaja jika tidak hanya di lakukan pada remaja sebagai subyek tapi juga kepada orangtua remaja yang akan menjadi model buat remaja. Green et al., 1980, dalam Notoatmodjo (2007) menyebutkan bahwa pendidikan kesehatan adalah suatu pengalaman pembelajaran yang dirancang untuk memotivasi pelaksanaan tindakan seseorang terkait masalah kesehatan sehingga ia dapat merawat dirinya sendiri secara individu atau secara bersama-sama.

Pada kelompok intervensi diketahui terjadi penurunan ansietas pada remaja setelah dilakukan terapi logo dan terapi suportif kelompok. Ansietas merupakan suatu respon normal individu terhadap pertumbuhan, perubahan, pengalaman baru, penemuan identitas dan makna hidup (Kaplan \& Sadock, 2005). Ansietas dapat terjadi pada semua tingkat usia, termasuk pada masa remaja. Hal ini disebabkan pada masa remaja, seorang individu mengalami masa transisi dari anak-anak menjadi dewasa dan mengalami perubahan baik fisik, sosial maupun psikologis (Cameron, 2004 dalam Santrock, 2003/2007; Dahl, 2004 dalam Videbeck, 2008). Ansietas pada remaja didefinisikan sebagai perasaan gelisah yang dihubungkan dengan suatu antisipasi terhadap bahaya yang sering terjadi pada saat proses perkembangan. Kecemasan yang terjadi pada masa remaja terjadi sepanjang masa perkembangan pada remaja sehingga mengganggu aktivitas sehari hari remaja (Verhulst et al., 1997; Ollendick \& HirshfeldBecker, 2002 dalam Santrock, 2003/2007).

Remaja yang rentan terhadap terjadinya ansietas salah satunya adalah remaja yang menjalani masa hukuman atas tindak kriminal yang telah dilakukan di rumah tahanan dan lembaga pemasyarakatan. Gosden et al. (2003) menyebutkan bahwa pada remaja 
yang menjalani masa hukuman karena tindak kriminal yang dialaminya $69,1 \%$ mengalami masalah gangguan mental termasuk ansietas. Hal tersebut dijelaskan pula pada beberapa penelitian yang menjelaskan bahwa gejala ansietas sering terlihat sepanjang rentang usia pada masa remaja (Ferdinand \& Verhulst, 1995; Pine et al., 1998 dalam Santrock, 2003/2007; Bittner et al., 2007; Brückl et al., 2007; Lewinsohn et al., 2008). Hal tersebut dibuktikan juga dalam penelitian ini yang menunjukkan bahwa pada kelompok intervensi sebagian besar remaja mengalami ansietas berat yaitu sejumlah 36 remaja dari 39 remaja kelompok intervensi atau berkisar (92,3\%). Dan pada kelompok kontrol sebagian besar remaja yang ada di rutan dan lapas mengalami ansietas berat juga yaitu sebesar $74,4 \%$ dari data tersebut.

Cara mengatasi ansietas ada beberapa terapi spesialis yang dapat diterapkan, antara lain terapi logo dan terapi suportif. Berdasarkan hasil uji statistik didapatkan bahwa tidak terdapat perbedaan yang signifikan antara tingkat ansietas remaja sebelum dan setelah terapi generalis. Hal ini terlihat dari nilai $p$ value $>0,05$ yaitu 0,157 . Berbeda dengan tingkat ansietas remaja setelah dilakukan terapi logo. Berdasarkan hasil uji statistik diketahui bahwa terdapat perbedaan yang signifikan antara tingkat ansietas sebelum terapi dan setelah terapi logo. Hal ini dibuktikan dengan nilai $p$ value perbedaan tingkat ansietas sebelum dan setelah terapi logo yaitu 0,001 artinya, bahwa $p$ value $<0,05$.

Hasil penelitian di atas sesuai dengan penelitian yang dilakukan oleh Routledge \& Juhl (2010) yang menyebutkan bahwa seorang individu yang kehilangan makna terhadap kejadian dalam hidupnya akan lebih mudah mengalami ansietas. Pencarian makna terhadap kejadian dalam hidup dapat dilakukan dengan terapi logo (Bastaman,
2007). Terapi logo dapat diterapkan pada remaja dengan memperhatikan hubungan terapeutik, meningkatkan pemahaman tentang nilai, identitas dan tujuan, menjelaskan tentang kerangka permasalahan yang dihadapi, membantu menemukan makna dari masalah yang dihadapi (Corey, 2001 dalam Blair, 2004).

Teknik terapi logo yang digunakan dalam penelitian ini adalah teknik paradoksikal intension dan derefleksi. Teknik paradoxical intention secara komposit nilai mempunyai pengaruh yang bermakna dalam mengatasi ansietas penduduk pasca gempa akan tetapi apabila dilihat pada masing-masing subvariabel (fisiologis, afektif, kognitif, dan perilaku) diketahui bahwa pada subvariabel afektif tidak menunjukkan pengaruh yang significant, hanya terjadi peningkatan nilai saja (Sutejo, 2009). Wijayanti (2010) yang melakukan penelitian tentang pengaruh terapi logo terhadap ansietas pada Narapidana perempuaan di Lapas Semarang tidak hanya menggunakan teknik paradoksikal intension tapi ditambah dengan teknik derefleksi. Hasil penelitian Wijayanti (2010) menunjukkan hal yang sama dengan penelitian Sutejo (2009) dimana secara komposit nilai penggunaan terapi logo dengan teknik paradoxical intention dan dereflection mempunyai pengaruh yang signifikan terhadap ansietas pada napi perempuan.

Remaja membutuhkan system pendukung yang kuat dalam menjalani tugas perkembangannya. Support sistem yang kuat pada remaja akan membuat remaja mempunyai ketahanan terhadap kondisi yang tidak menyenangkan (Ge et al., 1994; Mastern et al., 1994; Masten \& Hubbard, 1995 dalam Santrock, 2003/2007). Gamezy dan Masten (1993) dalam Santrock (2003/2007) telah mempelajari ketahanan remaja di tengah-tengah kesengsaraan dan ketidakberuntungan selama beberapa 
tahun. la menyimpulkan terdapat tiga faktor yang seringkali muncul membantu anak-anak dan remaja agar dapat memiliki ketahanan terhadapa stress: (1) keterampilan kognitif (perhatian dan pemikiran reflektif), (2) keluarga, termasuk mereka yang hidup dalam kemiskinan ditandai dengan adanya kehangatan, keterikatan satu sama lain, ada orang dewasa yang memperhatikan seperti kakek dan nenek yang bertanggung jawab meskipun tidak ada orangtua yang responsive karena adanya perselisihan hebat dalam pernikahan orangtua remaja tersebut, dan (3) ketersediaan sumber dukungan eksternal, seperti ketika adanya kebutuhan yang kuat akan tokoh ibu dapat dipenuhi oleh tokoh guru, tetangga, orangtua teman atau bahkan tokoh institusional seperti tokoh agama atau pegawai yang ada di lembaga tempat remaja tinggal.

Sampaio, Sequeira \& Lluch Canut (2015) menjelaskan bahwa salah satu psikoterapi yang dapat dipergunakan untuk mengatsi ansietas terutama pada masalah emosional dan berfokus pada bagaimana memfasilitasi remaja untuk mengenal dan mempergunakan support sistem yang mampu dijangkau adalah terapi suportif. Penelitian ini sejalan dengan penelitian yang telah dilakukan oleh Banowati (1989). Banowati (1989) menyatakan bahwa psikoterapi suportif yang dilakukan pada pasien hemiparase mampu menurunkan derajat depresi dan ansietas serta meningkatkan semangat hidup. Penelitian serupa yang dilakukan oleh Hasmilasari (2010) membuktikan juga bahwa dengan terapi suportif tingkat ansietas pada ibu hamil mengalami penurunan. Sedangkan penelitian lainnya yang pernah dilakukan oleh Shechtman \& Katz (2007) membuktikan bahwa terapi kelompok suportif cukup efektif untuk menurunkan tingkat ansietas sekelompok remaja yang mengalami gangguan belajar dalam membangun hubungan sosial dan persahabatan dengan orang lain. Setelah pemberian terapi selama 15 minggu, beberapa responden menyatakan manfaat dari pemberian terapi, karena memperoleh kesempatan untuk mengungkapkan perasaan dan berbagi pengalaman yang tidak menyenangkan dengan responden lainnya dalam satu kelompok.

Hal ini sesuai dengan hasil uji statistik penelitian yang memperlihatkan bahwa nilai $p$ value pengaruh terapi logo terhadap ansietas remaja $>p$ value pengaruh terapi logo dan terapi suportif. Hal tersebut berarti dengan penggabungan 2 psikoterapi lebih memberikan hasil yang optimal dibandingkan dengan hanya menggunakan salah satu terapi saja (Porter, 1993 dalam Kaplan dan Saddock, 1993).

Berbeda dengan apa yang telah peneliti ungkapkan sebelumnya, penelitian lain menyebutkan bahwa ansietas pada remaja lebih tepat diatasi dengan menggunakan terapi perilaku (desensitisasi, flooding, prosedur operan, modeling, dan terapi pikiran perilaku/CBT), terapi psikodinamik, terapi farmakologi (Berecz, 1968; Graziano et al., 1979; Carlson, Figueroa, \& Lahey, 1986; Gittelman, \& Koplewicz, 1986; Lewis, 1986; Morris \& Kratochwill, 1985 dalam Strauss, 1990), teknik penghentian pikiran (Cohen et al., 2000), psikoedukasi keluarga (Stuart \& Laraia, 2005), dan penggunaan mekanisme koping (Moskowitz dalam Bonanno \& Mayne, 2001; Townsend, 2009).

Berdasarkan hasil penelitian tentang pengaruh terapi logo dan terapi suportif terhadap ansietas remaja dan banyaknya psikoterapi yang dapat dipergunakan untuk mengatasi ansietas, maka hal ini bisa menjadi rekomendasi pada peneliti berikutnya untuk melihat perbandingan pengaruh antara terapi logo supportif dengan psikoterapi lain dalam mengatasi ansietas terutama ansietas pada remaja di rutan dan lapas. 
Hal ini sejalan dengan penelitian yang telah dilakukan oleh Bellino, Rinaldi \& Bogetto (2010) yang menjelaskan tentang perbandingan pengaruh kombinasi psikoterapi dan farmakologi dengan pengaruh farmakologi pada klien dengan gangguan kepribadian. Pada penelitian ini kombinasi psikoterapi dan farmakologi lebih berpengaruh terhadap tingkat ansietas klien dengan gangguan kepribadian.

Selain hal tersebut di atas psikoterapi lain yang juga mempunyai pengaruh terhadap ansietas adalah tindakan untuk mengatasi ansietas dapat dilakukan melalui penggunaan mekanisme koping (Moskowitz dalam Bonanno \& Mayne, 2001; Townsend, 2009; Lazarus \& Abramovitz, 2004 dalam Safaria, Safaria \& Saputra, 2009; Sarafino, 1998; Smer,1994 dalam Safaria, Safaria \& Saputra, 2009), psikofarmaka (Copel, 2000, dan Videbeck, 2008) dan terapi keperawatan (Bulechek et al., 2008). Terapi spesialis yang dapat dilakukan untuk mengatasi ansietas diantaranya adalah terapi kognitif (Varcarolis, 2006), terapi perilaku (Videbeck, 2008), teknik relaksasi (Stuart \& Laraia, 2005), modeling dan desensitisasi sistematik (Isaacs, 2005), flooding dan pencegahan respon (Varcarolis, 2006), thought stopping (Routledge \& Juhl, 2010), CBT (Zimmerman, McDermut \& Mattia, 2000), psikoedukasi keluarga (Stuart \& Laraia, 2005), ACT (Mauro \& Murray, 2000), terapi logo (Johnson, Lavoie, \& Mahoney, 2001; Isaacs, 2005; Frangkl, 1973/2008) serta terapi suportif (Banowati, 1989; Viederman, 2008; Lipsitz et al., 2008). Psikoterapipsikoterapi tersebut telah terbukti mampu lebih berpengaruh terhadap tingkat ansietas remaja di bandingkan dengan hanya dengan terapi generalis (Kaplan \& Saddock, 2005).

Kelemahan penelitian ini adalah intervensi yang diberikan pada responden dilakukan sendiri oleh peneliti sehingga membutuhkan waktu yang cukup lama dalam pengambilan data penelitian dan adanya potensi terjadinya bias dalam penelitian. Untuk penelitan selanjutnya disarankan intervensi dapat dilakukan oleh tenaga profesional yang tidak mengetahui terapi yang diberikan apakah pada kelompok intervensi ataukah pada kelompok kontrol.

\section{SIMPULAN}

Karakteristik remaja pada kelompok intervensi yang terlibat dalam penelitian di Rutan dan Lapas Wilayah Jawa Barat rata-rata berusia 16,74 tahun, penghasilan orangtua rata rata Rp. 725.740, pendidikan tamat SMP, pola asuh orangtua protective, mayoritas mengalami ansietas berat. Sedangkan karakteristik remaja pada kelompok kontrol yang terlibat dalam penelitian di Rutan dan Lapas Wilayah Jawa Barat rata-rata berusia 16,97 tahun, Penghasilan orangtua rata rata Rp. 1.1016.670, pendidikan tamat SMP, pola asuh orangtua protective dan mayoritas mengalami ansietas berat. Terapi logo dan terapi suportif memberikan pengaruh yang signifikan terhadap penurunan ansietas remaja di rutan dan lapas wilayah Jawa Barat yang ditandai dengan adanya perbedaan tingkat ansietas sebelum dan setelah di berikan terapi logo dan terapi suportif pada remaja di rutan dan lapas pada kelompok intervensi. Tingkat ansietas remaja setelah diberikan terapi logo dan terapi suportif pada kelompok intervensi berbeda secara signifikan dengan tingkat ansietas remaja setelah diberikan terapi logo dan terapi suportif pada kelompok kontrol.

Saran dari penelitian ini ditujukan bagi Aplikasi Keperawatan, keilmuan dan pendidikan serta metodologi. Pada aplikasi keperawatan, Kanwil hukum dan HAM Provinsi Jawa Barat diharapkan menyampaikan kepada seluruh Kalapas dan Karutan di wilayah Provinsi Jawa Barat untuk meningkatkan perhatian terhadap 
masalah kesehatan mental remaja yang menjalani masa hukuman di rutan dan lapas terutama pada remaja yang masih mengalami ansietas berat dengan melakukan pemeriksaan berkala terhadap status mental remaja dan memberikan penanganan secara medis maupun non medis serta melakukan pembinaan yang intensif tidak hanya pada remaja yang menjalani masa hukuman di Rutan dan Lapas tapi juga memberikan pendidikan kesehatan secara berkala kepada orangtua remaja yang melakukan kunjungan terhadap remaja sehingga orangtua memahami perkembangan remaja, kemungkinan masalah yang dihadapi oleh remaja dan tindakan yang bisa dilakukan orangtua untuk mengantisipasi hal tersebut.

Perawat spesialis keperawatan jiwa hendaknya menjadikan terapi logo dan terapi suportif sebagai salah satu kompetensi yang dapat dilakukan pada pelayanan kesehatan jiwa khususnya masalah ansietas pada remaja akhir di masyarakat (berbasis komunitas). Saran peneliti yang ditujukan untuk keilmuan dan pendidikan keperawatan yaitu pihak pendidikan tinggi keperawatan hendaknya dapat menggunakan hasil penelitian ini sebagai evidence based dengan lebih mengeksplorasi konsep dan teori keperawatan jiwa dalam mengembangkan teknik penerapan penggabungan terapi logo dan terapi suportif bagi masalah keperawatan jiwa, pihak pendidikan tinggi keperawatan hendaknya dapat bekerja sama dengan pihak Rutan dan Lapas untuk melakukan intervensi keperawatan baik pemberian terapi generalis maupun terapi spesialis terhadap remaja yang berada di rutan dan lapas.

\section{DAFTAR PUSTAKA}

Asrori, A. (2016). Terapi kognitif perilaku untuk mengatasi gangguan kecemasan sosial. Jurnal IImiah Psikologi Terapan, 3(1): 89-107.
Banowati, L. (1989). Psikoterapi suportif sebagai teknik untuk menurunkan derajat depresi dan ansietas serta meningkatkan semangat hidup pasien hemiparese. Supportive Psychotherapy as a technique to decrease levels of depression and anxiety and increasing patient's life spirit following hemiparesis (tesis). Fakultas Psikologi, Universitas Indonesia, Jakarta, Indonesia.

Bastaman, H. D. (2007). Logoterapi: Psikologi untuk menemukan makna hidup dan meraih hidup bermakna. Jakarta: PT. Raja Grafindo Persada.

Bektas, M., \& Ozturk, C. (2008). Effect of health promotion education on presence of positive health behaviors, level of anxiety and self-concept. Social Behavior and Personality: An international journal, 36(5): 681-690.

Bellino, S., Rinaldi, C., \& Bogetto, F. (2010). Adaptation of interpersonal psychotherapy to borderline personality disorder: a comparison of combined therapy and single pharmacotherapy. The Canadian Journal of Psychiatry, 55(2): 74-81.

Bittner, A., Egger, H. L., Erkanli, A., Costello, E. J., Foley, D. L., \& Angold, A. (2007). What do childhood anxiety disorders predict?. Journal of Child Psychology and psychiatry, 48(12): 1174-1183.

Blair, R. G. (2004). Helping older adolescents search for meaning in depression. Journal of Mental Health Counseling, 26(4): 333-347.

Bonanno, G. A. \& Mayne, T. J. (2001). The future of emotion research. Emotions: Current issues and future directions, 398-410.

Brückl, T. M., Wittchen, H. U., Höfler, M., Pfister, H., Schneider, S., \& Lieb, R. (2007). Childhood separation anxiety and the risk of subsequent psychopathology: Results 
from a community study. Psychotherapy and Psychosomatics, 76(1): 47-56.

Bulechek, G. M., Butcher, H. K., Dochterman, J. M., \& Wagner, C. (2008). Nursing interventions classifications (NIC). St. Louis: Mosby.

Canadian Psychiatric Association. (2006). Clinical practice guidelines. Management of anxiety disorders. Canadian journal of psychiatry. Revue canadienne de psychiatrie, 51(8 Suppl 2): 9S.

Cohen, J. A., Mannarino, A. P., Berliner, L., \& Deblinger, E. (2000). Traumafocused cognitive behavioral therapy for children and adolescents: An empirical update. Journal of Interpersonal Violence, 15(11): 1202-1223.

Colins, O., Vermeiren, R., Vreugdenhil, C., van den Brink, W., Doreleijers, T., \& Broekaert, E. (2010). Psychiatric disorders in detained male adolescents: A systematic literature review. The Canadian Journal of Psychiatry, 55(4): 255-263.

Departemen Kesehatan Republik Indonesia. (2016). Situasi Kesehatan reproduksi remaja. Retrieved from http://www. depkes.go.id/resources/download/ pusdatin/infodatin/infodatin $\% 20$ reproduksi\%20remaja-ed.pdf.

Departemen Sosial Republik Indonesia. (2002). Program nasional bagi anak indonesia kelompok perlindungan anak terhadap abuse, kekerasan, eksploitasi dan diskriminasi. Retrieved from www.bappenas.go.id/get-file-server/ node/330/

Ferdinand, R. F., \& Verhulst, F. C. (1995). Psychopathology from adolescence into young adulthood: an 8-year followup study. The American journal of psychiatry, 152(11): 1586.

Fergusson, D. M., Boden, J. M., \& Horwood, L. J. (2007). Recurrence of major depression in adolescence and early adulthood, and later mental health, educational and economic outcomes. The British Journal of Psychiatry, 191(4): 335-342.

Fiandini, S. P. (2011). Pengaruh pemberian teknik relaksasi nafas dalam terhadap tingkat kecemasan pasien pre-operasi di ruang bedah RSD dr. Soebandi Jember (Skripsi). Program Studi IImu Keperawatan, Universitas Jember, Jawa Timur, Indonesia.

Frangkl, V. E. (2008). Optimisme di tengah tragedi: Analisis logoterapi. (Alih Bahasa: Lala Herawati Dharma). Bandung: Nuansa. (Buku asli diterbitkan1973).

Ge, X., Lorenz, F. O., Conger, R. D., Elder, G. H., \& Simons, R. L. (1994). Trajectories of stressful life events and depressive symptoms during adolescence. Developmental psychology, 30(4): 467. Gosden, N. P., Kramp, P., Gabrielsen, G., \& Sestoft, D. (2003). Prevalence of mental disorders among 15-17 $\square$ yearold male adolescent remand prisoners in Denmark. Acta Psychiatrica Scandinavica, 107(2): 102-110.

Goulet, L. R. \& Baltes, P. B. (Eds.). (2013). Life-span developmental psychology: Research and theory. New York: Academic Press.

Hage, S. M. (2006). A closer look at the role of spirituality in psychology training programs. Professional Psychology: Research and Practice, 37(3): 303.

Hasmilasari. (2010). Pengaruh terapi kelompok suportif terhadap ansietas ibu hamil primipara di Kelurahan Balumbang Jaya, Bogor (tesis). Program Studi Magister Keperawatan, Fakultas IImu Keperawatan Universitas Indonesia, Depok, Indonesia.

Irawan, A. (2011). Resosialisasi narapidana anak berkaitan dengan efektifitas pola pembinaan narapidana di Lembaga 
Pemasyarakatan Anak: Studi kasus Lembaga Pemasyarakatan Anak Kelas II-B Tanjung Pati Sumatera Barat (tesis). Program Pasca Sarjana IImu Hukum, Universitas Andalas, Padang, Indonesia.

Isaacs, A. (2005). Panduan belajar keperawatan kesehatan jiwa dan psikiatrik (Lippincot's review series: Mental health and psychiatric nursing) (Edisi 3). Alih Bahasa: Dean Patry Rahayuningsih). Jakarta: EGC.

Johnson, H. D., Lavoie, J. C., \& Mahoney, M. (2001). Interparental conflict and family cohesion: Predictors of Ioneliness, social anxiety, and social avoidance in late adolescence. Journal of Adolescent Research, 16(3): 304-318.

Kaplan, H. I., \& Sadock, B. J. (1993). Comprehensive group psychotherapy. ( $\left.3^{\text {rd }} \mathrm{Ed}\right)$. Maryland: Williams \& Wilkins Co.

Kaplan, S. \& Sadock, B. J. (2005). Comprehensive handbook of psychiatry. Maryland: Wiliam \& Wilkins.

Program Profesi Ners Universitas Padjajaran. (2011). Laporan Praktek Profesi Ners Universitas Padjadjaran. Tidak dipublikasikan.

Lazarus, A. A. \& Abramovitz, A. (2004). A multimodal behavioral approach to performance anxiety. Journal of clinical psychology, 60(8): 831-840.

Lewinsohn, P. M., Holm-Denoma, J. M., Small, J. W., Seeley, J. R., \& Joiner Jr, T. E. (2008). Separation anxiety disorder in childhood as a risk factor for future mental illness. Journal of the American Academy of Child \& Adolescent Psychiatry, 47(5): 548-555.

Lipsitz, J. D., Gur, M., Vermes, D., Petkova, E., Cheng, J., Miller, N., ... \& Fyer, A. J. (2008). A randomized trial of interpersonal therapy versus supportive therapy for social anxiety disorder. Depression and Anxiety, 25(6): 542-553.
Manik, C. G. (2007). Analisa faktor-faktor yang mempengaruhi konsep diri pada narapidana remaja di Lembaga Pemasyarakatan Kelas II A Anak Tanjung Gusta Medan (Skripsi). Program Studi Keperawatan, Fakultas Kedokteran, Universitas Sumatera Utara, Medan, Indonesia.

Masngudin, H. M. S. (2004). Kenakalan remaja bebagai perilaku menyimpang hubungannya dengan keberfungsian sosial keluarga: Kasus di Pondok Pinang Pinggiran Kota Metropolitan Jakarta. Retrieved from http://www.depsos.go.id/ Balatbang/Puslitbang\%20UKS/2004/ Masngudin.htm

Mauro, M. V \& Murray, S. B. (2000). Quality of life in individual with anxiety. Journal Psychitric from American Psychiatric Association, 157(1): 669-682.

Mu'afiro, A. (2004). Pengaruh hypnosis lima jari terhadap penurunan kecemasan pasien kanker leher rahim di ruang kandungan RSU Dr. Soetomo Surabaya (tesis). Universitas Gadjah Mada, Yogyakarta, Indonesia.

Notoatmojo, S. (2007). Pendidikan dan perilaku kesehatan. Jakarta: Rineka Cipta.

Oliva, A., Jiménez, J. M., \& Parra, A. (2009). Protective effect of supportive family relationships and the influence of stressful life events on adolescent adjustment. Anxiety, Stress, \& Coping, 22(2): 137-152.

Routledge, C., \& Juhl, J. (2010). When death thoughts lead to death fears: Mortality salience increases death anxiety for individuals who lack meaning in life. Cognition and Emotion, 24(5): 848854.

Sadock, B. J., \& Sadock, V. A. (2011). Kaplan and Sadock's synopsis of psychiatry: Behavioral sciences/clinical psychiatry. 
Lippincott Williams \& Wilkins.

Sadock, B. J., \& Sadock, V. A. (2009). Concise textbook of child and adolescent psychiatry. Philadelphia: Lippincott Williams \& Wilkins.

Safaria, Safaria, T. \& Saputra, N. E. (2009). Manajemen emosi-Sebuah panduan cerdas bagaimana mengelola emosi positif dalam hidup Anda (Cetakan Pertama). Jakarta: PT Bumi Aksara.

Sampaio, F. M. C., Sequeira, C. A. D. C., \& Lluch Canut, M. T. (2015). Nursing psychotherapeutic interventions: A review of clinical studies. Journal of clinical nursing, 24(15-16): 2096-2105.

Santrock, J.W. (2007). Adolesence (Remaja). (Edisi ke-11). (Alih Bahasa: Soedjarwo). Jakarta: Penerbit Erlangga. (Buku asli terbit 2003).

Santrock, J. (2015). Essentials of life-span development. London: McGraw-Hill Higher Education.

Shechtman, Z. \& Katz, E. (2007). Therapeutic bonding in group as an explanatory variable of progress in the social competence of students with learning disabilities. Group Dynamics: Theory, Research, and Practice, 11(2): 117.

Steinberg, L. (2005). Cognitive and affective development in adolescence. Trends in cognitive sciences, 9(2): 69-74.

Strauss, C. C. (1990). Anxiety disorders of childhood and adolescence. School Psychology Review, 19(2): 142.

Stuart, G.W., and Laraia, M.T. (2005). Principles and practice of psyhiatric nursing. ( $8^{\text {th }}$ ed.). St. Louis: Mosby Year B.

Supeno, H. (2009). Perlindungan hukum anak. Retrieved from http://hadisupeno. com/wawancara/65-perlindunganhukum-anak.html

Sutejo. (2009). Pengaruh logoterapi terhadap ansietas pada penduduk pasca gempa di Kabupaten Klaten Provinsi Jawa Tengah (Tesis). Program Studi Magister Keperawatan, Universitas Indonesia. Jakarta, Indonesia.

Townsend, M. C. (2009). Psychiatric mental health nursing $\left(6^{\text {th }} \mathrm{Ed}\right)$. Philadhelpia: Davis Company.

Van der Laan, A., \& Eichelsheim, V. (2013). Juvenile adaptation to imprisonment: Feelings of safety, autonomy and wellbeing, and behaviour in prison. European Journal of Criminology, 10(4): 424-443.

Varcarolis, E. M. (2006). Psychiatric nursing clinical guide: Assesment tools and diagnosis. Philadelphia: W.B Saunders Co.

Videbeck, S.L. (2008). Psychiatric mental health nursing $\left(4^{\text {rd }} \mathrm{Ed}\right)$. Philadhelpia: Lippincott Williams \& Wilkins.

Viederman, M. (2008). A model for interpretative supportive dynamic psychotherapy. Psychiatry, 71(4): 349358.

Wijayanti, D. Y. (2010). Pengaruh logo therapy kelompok terhadap Kecemasan pada narapidana di LAPAS perempuan Semarang Jawa Tengah Tahun 2010 (tesis). Program Studi Magister Keperawatan, Universitas Indonesia, Jakarta, Indonesia.

Zhou, J., Witt, K., Zhang, Y., Chen, C., Qiu, C., Cao, L., \& Wang, X. (2014). Anxiety, depression, impulsivity and substance misuse in violent and nonviolent adolescent boys in detention in China. Psychiatry research, 216(3): 379384.

Zimmerman, M., McDermut, W., \& Mattia, J. I. (2000). Frequency of anxiety disorders in psychiatric outpatients with major depressive disorder. American Journal of Psychiatry, 157(8): 1337-1340. 